UDC 616.65-002-006

DOI: 10.21668/health.risk/2019.2.13.eng

\title{
EPIDEMIOLOGY OF PROSTATE CANCER In KURSK REGION
}

\section{I.L. Kiselev, A.A. Pol'shin}

Kursk Regional Clinical Oncology Hospital, 1Eliseeva Str., Kislino, Kursk District, 305524, Russian Federation

\begin{abstract}
The paper dwells on analysis performed on 2,238 male patients with primary incidence and 999 patients who died due to prostate cancer over 2007-2016 in Kursk region.

Data were processed with "Statistica for Windows" software package (ver. 12.5). The authors applied intensive overall and sex-age (per 100 thousand males) parameters. Overall incidence and mortality were compared with the data collected in the Central Federal District. Sex-age incidence and mortality due to prostate cancer were compared with the same parameters in the Russian Federation as a whole. To test validity of discrepancy between data sets, Student's parametric test (t) was applied with $95 \%$ significance. Incidence and mortality due to prostate cancer were predicted for a period up to 2021 with an autoregressive integrated moving average (ARIMA).

Prostate cancer occupies the fifth place among malignant neoplasms in Kursk region and the sixth place in the overall mortality structure. In Kursk region a growth in incidence with prostate cancer amounted to $100.3 \%$ in 2016 against 2007; a growth in mortality, 85.6\%. By 2021 incidence with prostate cancer can reach 71.24, and mortality, 30.79. Incidence among males in Kursk region has grown due to an increase in number of male patients aged 60-64 and 80 and older. Mortality caused by prostate cancer has grown due to an increase in number of deceased males aged 50 and older.

In the nearest future Kursk region can take a leading place among other regions in the Central federal District as per incidence and mortality due to prostate cancer. The research results are being applied for planning and developing a regional target program "Oncology".

Key words: malignant neoplasms, epidemiologic analysis, incidence, mortality, prostate cancer, sex-age parameters, target program.
\end{abstract}

Prostate cancer $(\mathrm{PC})$ is one of the most widely spread malignant neoplasms in men [1-3]. Incidence with PC has increased significantly over recent years [4-5]. Researchers revealed that incidence with $\mathrm{PC}$ was higher in highly developed countries, and the lowest incidence with the disease was detected in the least developed countries [6].

Incidence with PC varies worldwide and discrepancies between different population groups can be more than 50 times $[7,8]$. The highest incidence with PC is observed in Australia / New Zealand (111.6), in North America (97.2), and in Western Europe (85.8); the lowest one is registered in South and Central Asia (4.5) [7]. Regions where incidence level is substantial in comparison with other regions located on the same continent include South Africa (61.7), Western Asia (28.0),
North America, Western Europe (85.8), and Australia / New Zealand (111.6) [8].

Ageing of population leads to a growth in life expectancy and causes risks of PC in future [7]. Risk of the disease is equal to approximately 1:10,000 among people younger than 40; still, each sixth man will have PC diagnosed in him over his life span. Men younger than 50 account for only $0.1 \%$ of patients with PC. Risk of the disease increases substantially only among those who are older than 60. Average age of male patients with PC amounts to 72-74 [9].

There are several risk factors causing the disease; primary ones are low physical activity, overweight, alcohol intake, consumption of red meat, inflammatory diseases in the kidneys and urinary bladder etc. [9, 10, 11]. 20.3 million new PC cases are predicted to be

(C) Kiselev I.L., Pol'shin A.A., 2019

Igor' L. Kiselev - Candidate of Medical Sciences, Associate Professor at the Oncology Department, Chief physician (e-mail: igor.leonidovich.kiselev@ya.ru; tel.: +7(4712)73-19-43; ORCID: https://orcid.org/0000-0001-6632-1753).

Aleksei A. Pol'shin - Oncologist, urologist (e-mail: ligrigam@yandex.ru; tel.: +7 (910) 316-02-64; ORCID: https://orcid.org/0000-0001-8266-9725). 
detected by 2030 , and 13.2 million patients form them will not survive $[5,7]$.

An issue related to PC screening is rather controversial $[9,12,13]$. Primary PC treatment usually involves eradication of the prostate, radiotherapy and hormonal therapy, but sometimes it can be only medical supervision. Choice on a therapy depends on age, cancer stage, comorbidity, preference of a patient and an urologist etc. [14].

Mortality caused by PC remains the highest and occupies the second rank place after mortality caused by lung cancer $[1,2,7]$. Frequency and prevalence of $\mathrm{PC}$ differ in different world regions [7, 8]. In $2012 \mathrm{PC}$ was diagnosed in 1.1 million men, and $70 \%$ out of them (795,000 cases) were registered in developed countries $[6,8,9]$.

In the Russian Federation incidence with PC grew from 30.74 per 100,000 men in 2007 to 59.91 per 100,000 in 2017 ; the growth amounted to $100.5 \%$. Average age at which a male patient was diagnosed PC became younger in 2017 as it fell to 69.6 while in 2007 it was equal to $70.5[15,16,17]$. In the Russian Federation PC occupied the second rank place among malignant neoplasm in men in 2017 after malignant neoplasms in the trachea, bronchial tubes, and lungs (17.4\%) and accounted for $14.5 \%$ [15].

Mortality caused by PC grew from 13.54 pr 100,000 men in 2007 to 18.46 per 100,000 men in 2017 in the Russian Federation; the growth amounted to $34.27 \%$. PC occupied the second rank place in mortality caused by malignant neoplasms and accounted for $8.1 \%$; the first rank place belonged to malignant neoplasms in the trachea, bronchial tubes, lungs, and stomach (10.7\%) [15].

Mortality caused by malignant neoplasms is a basic indicator of public healthcare efficiency. But still, statistical data are often distorted due to necessity to encode death causes of oncologic patients. It happens due to migration, errors related to filling in death certificates, incorrect determination of the primary death cause, incompetent personnel filling in medical death certificates etc. $[18,19]$.
Our research goal was to analyze $\mathrm{PC}$ epidemiology in a specific Russian region (by the example of Kursk region).

Data and methods. To accomplish the research, we took data from the cancer register collected over 2007-2016by the Kursk regional cancer clinic on 2,238 patients who had PC diagnosed for the first time and on 999 patients who died from PC. According to official statistic data, male population in Kursk region decreased from 531,102 in 2007 to 509,615 in 2016. Data were statistically processed with «Statistica for Windows» software (ver. 12.5). We applied "crude" (total and age-sex) intensive (per 100,000 men) incidence and mortality values according to the Methodical guidelines developed by P.A. Herzen's Moscow Scientific Research Oncologic Institute [20]. Total "crude" incidence and mortality values were compared with data collected in the Central Federal District (CFD) over 2007-2016. «Crude» age-sex incidence and mortality values were compared with the same official statistic data in the overall country over the same period [15]. To test validity of discrepancy between data arrays, we applied parametric Student's t-test with significance level being equal to 95\%. Incidence and mortality caused by PC were predicted with autoregressive integrated moving average (ARIMA) [21] for a period up to 2021 .

Results and discussion. PC accounted for $5 \%$ in the structure of incidence with malignant neoplasms in Kursk region and occupied the 5th rank place after skin neoplasms (13.1\%), lung and breast cancer (10.9\% each), stomach cancer (7.1\%), and colon cancer $(5.1 \%)$.

Average incidence with PC amounted to 41.03 per 100,000 in Kursk region over 2007-2016 and was authentically lower than in the CFD (51.63 per 100,000 men) over the same period of time, $\mathrm{t}=2.12, \mathrm{p}=0.05$.

But still, a growth in incidence with PC in 2016 against 2007 was more apparent in Kursk region (100.3\%) than in the CFD $(84.5 \%)$. Incidence with $\mathrm{PC}$ in Kursk region grew from 28.55 per 100.000 men in 2007 to 
57.19 per 100,000 men in 2016 ; in the CFD it grew from 31.99 per 100,000 men in 2007 to 59.03 per 100,000 men in 2016 . As predicted, by 2021 incidence with PC will have grown up to 71.24 per 100,000 men in Kursk region (Figure 1).
Kursk region occupied the 13th place among all the region in the CFD as per primary incidence with PC over 2007-2016 (Table 1). Therefore, in the nearest future Kursk region will take a leading place as per incidence with $\mathrm{PC}$ among CFD regions.

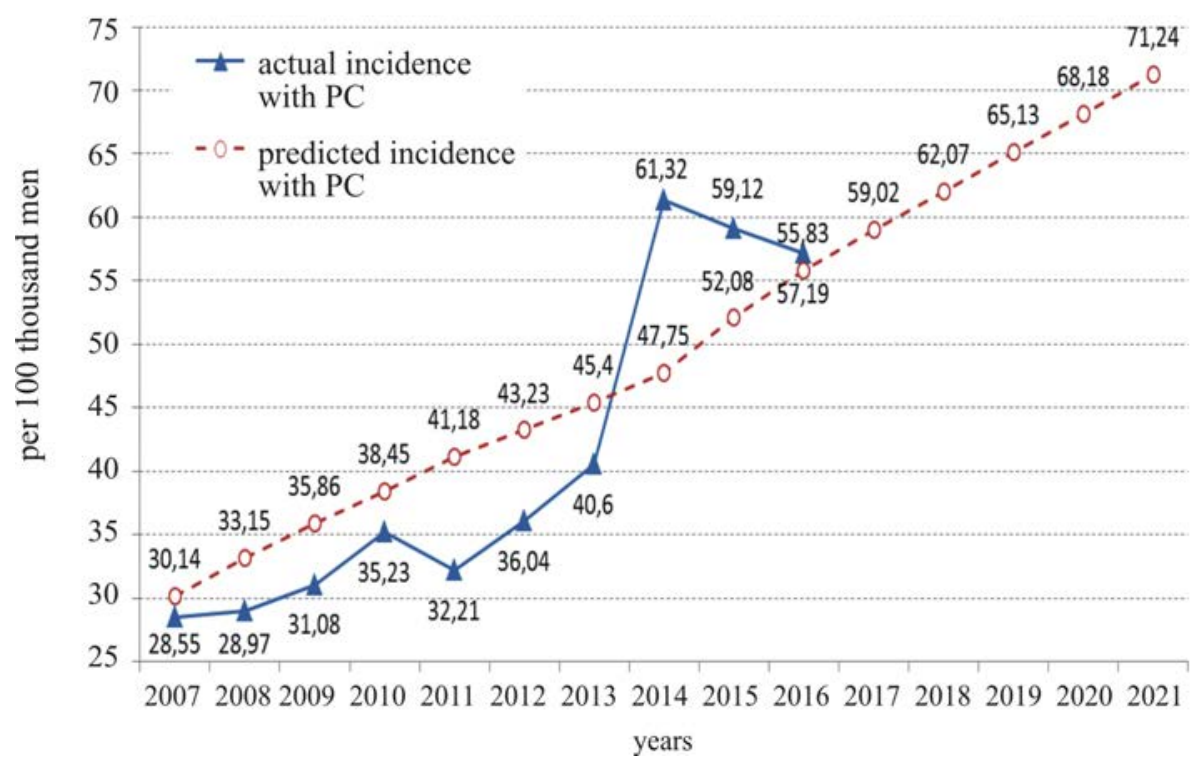

Figure 1. A prediction for incidence with PC in Kursk region

Table 1

Dynamics of incidence with prostate cancer in the Central Federal District regions

\begin{tabular}{|l|c|c|c|c|}
\hline \multirow{2}{*}{\multicolumn{1}{c|}{ Regions }} & \multicolumn{4}{|c|}{ Incidence (per 100 thousand men) } \\
\cline { 2 - 5 } & 2007 & 2016 & $\begin{array}{c}\text { average } \\
(2007-2016)\end{array}$ & $\begin{array}{c}\text { A growth in 2016 } \\
\text { against 2007 (\%) }\end{array}$ \\
\hline CFD & 31.99 & 59.03 & 51.63 & 84.5 \\
\hline Belgorod region & 28.94 & 45.73 & 40.52 & 58.0 \\
\hline Bryansk region & 31.94 & 40.44 & 43.96 & 26.6 \\
\hline Vladimir region & 25.6 & 50.75 & 40.32 & 98.2 \\
\hline Voronezh region & 36.55 & 59.56 & 51.38 & 63.0 \\
\hline Ivanovo region & 28.02 & 77.49 & 46.57 & 176.6 \\
\hline Tver region & 31.82 & 58.82 & 47.73 & 84.9 \\
\hline Kaluga region & 44.19 & 83.28 & 62.99 & 88.5 \\
\hline Kostroma region & 26.76 & 39.95 & 37.31 & 49.3 \\
\hline Kursk region & 28.55 & 57.19 & 41.03 & 100.3 \\
\hline Lipetsk region & 35.85 & 64.04 & 44.92 & 78.6 \\
\hline Moscow city & 66.12 & 68.39 & 70.78 & 3.4 \\
\hline Moscow region & 33.44 & 51.82 & 45.04 & 55.0 \\
\hline Orel region & 29.21 & 61.43 & 46.86 & 110.3 \\
\hline Ryazan region & 28.74 & 57.36 & 47.12 & 99.6 \\
\hline Smolensk region & 18.68 & 35.63 & 28.17 & 90.7 \\
\hline Tambov region & 19.22 & 41.73 & 35.34 & 117.1 \\
\hline Tula region & 33.76 & 53.95 & 44.31 & 59.8 \\
\hline Yaroslavl region & 29.67 & 62.62 & 47.83 & 111.1 \\
\hline
\end{tabular}


In Kursk region men who had PC diagnosed in them for the first time were 35-39 years old ( 0.54 per 100 thousand men), a peak in incidence (367.49 per 100 thousand men) was detected among those aged 75-79 with subsequent fall among those aged 80 and older (316.42 per 100 thousand men). It was quite consistent with data collected in the country in general (Table 2). Authentically $(p<0.05)$ lower sex-age incidence with PC in Kursk region than in the RF on average was detected among men aged 55-59 (46.02 per 100 thousand men against 60.40 per 100 thousand men in the $\mathrm{RF}$ on average, $\mathrm{t}=3.23, \mathrm{p}=0.05)$; men aged 60-64 (112.50 per 100 thousand men against 154.95 per 100 thousand men in the country on average, $\mathrm{t}=3.7, \mathrm{p}=0.002)$; and among men aged 70-74 (303.39 per 100 thousand men against 383.50 per 100 thousand men in the RF on average, $\mathrm{t}=2.24, \mathrm{p}=0.04$ ).

In Kursk region dynamics of sex-age incidence with PC was multidirectional among men aged 35-44 and there was no growth detected in it. Sex-age incidence decreased among men aged 45-59, with the most significant drop $(-70,0 \%)$ being detected among men aged $50-54$. Sex-age incidence with PC grew among men aged 60-80 and older, its growth being higher among those aged 80 and older (123.6\%).

As for the RF in general, sex-age incidence with PC grew practically in all age

groups, excluding 35-39 and 55-59 years; the most significant growth was detected among men aged 65-69 (70.3\%); the least significant $(8.3 \%)$, among those aged 80 and older (Table 2).

In Kursk region prostate cancer took the 6th place $(4.5 \%)$ in the structure of mortality caused by malignant neoplasms after lung cancer $(17.9 \%)$, stomach cancer $(11.5 \%)$, breast cancer $(7.2 \%)$ colon and rectal cancer $(5.8 \%$ each), and pancreas cancer (4.6\%).

We didn't detect any authentic discrepancies in mortality caused by PC in Kursk region (its average value over 10 years being equal 18.89 per 100 thousand men) and in the CFD (18.51 per 100 thousand men), $p>0.05$. However, mortality growth in 2016 against 2007 was equal to $85.8 \%$ in Kursk region and it was higher than in the CFD (35.24\%). In Kursk region mortality caused by PC grew from 13.43 per 100 thousand men in 2007 to 24.96 per 100 thousand men in 2016; in the CFD it grew from 15.38 per 100 thousand men in 2007 to 20.80 per 100 thousand men in 2016.

Unless the situation changes, mortality caused by PC can reach 30.79 per 100 thousand men in Kursk region (Figure 2).

Kursk region occupied the 18 th place as per PC-caused mortality over 2007-2016 among all the CFD regions (Table 3 ).

Table 2

Comparison of sex-age incidence with prostate cancer (per 100 thousand men of a relevant age) (average values for 2007-2016)

\begin{tabular}{|c|c|c|c|c|c|c|}
\hline \multirow[b]{2}{*}{ Age } & Kursk region & \multirow{2}{*}{$\begin{array}{c}\text { Growth/decrease } \\
\text { in } 2016 \text { against } \\
2007(\%)\end{array}$} & The RF & \multirow{2}{*}{$\begin{array}{c}\text { Growth/decrease } \\
\text { in } 2016 \text { against } \\
2007(\%)\end{array}$} & \multirow[b]{2}{*}{$\mathrm{t}$} & \multirow[b]{2}{*}{$\mathrm{p}$} \\
\hline & $\bar{x} \pm \sigma$ & & $\overline{\mathrm{x}} \pm 6$ & & & \\
\hline $35-39$ & $0.54 \pm 1.13$ & 0 & $0.25 \pm 0.1$ & 0 & 0.76 & 0.46 \\
\hline $40-44$ & $0.28 \pm 0.90$ & 0 & $0.91 \pm 0.13$ & 26.9 & 2.06 & 0.06 \\
\hline $45-49$ & $2.54 \pm 1.58$ & -30.0 & $4.16 \pm 0.46$ & 38.8 & 2.95 & $0.01 *$ \\
\hline $50-54$ & $14.79 \pm 9.72$ & -70.0 & $19.21 \pm 2.86$ & 47.9 & 1.31 & 0.21 \\
\hline $55-59$ & $46.02 \pm 10.83$ & -22.5 & $60.40 \pm 8.16$ & -6.0 & 3.23 & $0.01 *$ \\
\hline $60-64$ & $112.50 \pm 29.33$ & 42.8 & $154.95 \pm 18.97$ & 39.7 & 3.7 & $0.002 *$ \\
\hline $65-69$ & $240.05 \pm 65.68$ & 61.5 & $279.07 \pm 59.22$ & 73.1 & 1.35 & 0.19 \\
\hline $70-74$ & $303.39 \pm 91.39$ & 50.5 & $383.50 \pm 58.48$ & 53.6 & 2.24 & $0.04 *$ \\
\hline $75-79$ & $367.49 \pm 140.97$ & 54.8 & $434.49 \pm 70.29$ & 55.0 & 1.29 & 0.22 \\
\hline $\begin{array}{c}80 \text { and } \\
\text { older }\end{array}$ & $316.42 \pm 108.90$ & 123.6 & $346.89 \pm 23.02$ & 8.3 & 0.83 & 0.42 \\
\hline
\end{tabular}

*note: $\overline{\mathrm{x}}$ is average value, $\sigma$ is standard deviation; $\mathrm{t}$ is Student's test, $\mathrm{p}$ is significance level. 


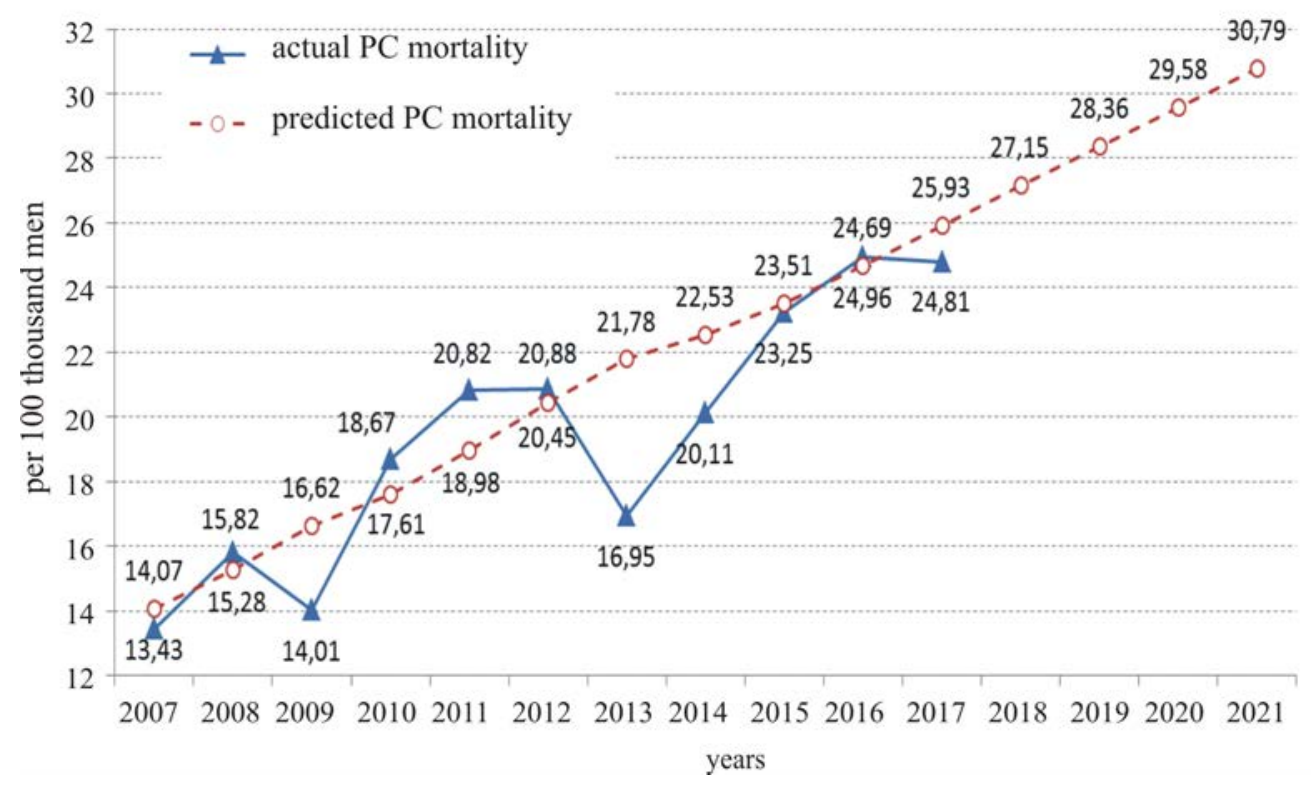

Figure 2. Predicted mortality caused by prostate cancer in Kursk region

Table 3

Dynamics of mortality caused by prostate cancer in the Central Federal District regions

\begin{tabular}{|l|c|c|c|c|}
\hline \multirow{2}{*}{\multicolumn{1}{c|}{ Regions }} & \multicolumn{3}{|c|}{ Mortality (per 100 thousand men) } \\
\cline { 2 - 5 } & 2007 & 2016 & $\begin{array}{c}\text { average } \\
(2007-2016)\end{array}$ & $\begin{array}{c}\text { growth/decrease } \\
\text { in 2016 against } \\
2007(\%)\end{array}$ \\
\hline CFD & 15.38 & 20.80 & 18.51 & 35.2 \\
\hline Belgorod region & 11.23 & 18.60 & 16.14 & 65.6 \\
\hline Bryansk region & 17.48 & 20.94 & 18.08 & 19.8 \\
\hline Vladimir region & 16.55 & 20.30 & 19.20 & 22.7 \\
\hline Voronezh region & 14.81 & 19.04 & 18.13 & 28.6 \\
\hline Ivanovo region & 12.24 & 20.56 & 16.30 & 68.0 \\
\hline Tver region & 15.02 & 24.85 & 18.18 & 65.5 \\
\hline Kaluga region & 19.91 & 24.83 & 20.14 & 24.7 \\
\hline Kostroma region & 16.37 & 21.15 & 17.51 & 29.2 \\
\hline Kursk region & 13.43 & 24.96 & 18.89 & 85.9 \\
\hline Lipetsk region & 12.95 & 17.24 & 15.29 & 33.1 \\
\hline Moscow city & 17.79 & 23.31 & 19.76 & 31.0 \\
\hline Moscow region & 17.62 & 16.59 & 18.57 & -5.9 \\
\hline Orel region & 16.35 & 20.18 & 19.19 & 23.4 \\
\hline Ryazan region & 15.13 & 23.33 & 19.68 & 54.2 \\
\hline Smolensk region & 11.03 & 18.38 & 14.45 & 66.6 \\
\hline Tambov region & 14.86 & 13.50 & 14.25 & -9.2 \\
\hline Tula region & 17.38 & 23.59 & 21.49 & 35.7 \\
\hline Yaroslavl region & 16.62 & 22.10 & 18.87 & 33.0 \\
\hline
\end{tabular}


Comparison of sex-age mortality caused by prostate cancer (per 100 thousand men of a relevant age) (average values for 2007-2016)

\begin{tabular}{|c|c|c|c|c|c|c|}
\hline & Kursk region & \multirow{2}{*}{$\begin{array}{c}\text { Growth/ } \\
\text { decrease } \\
\text { in } 2016 \text { against } \\
2007(\%)\end{array}$} & The RF & \multirow{2}{*}{$\begin{array}{c}\text { Growth/ } \\
\text { decrease } \\
\text { in } 2016 \text { against } \\
2007(\%)\end{array}$} & \multirow[b]{2}{*}{$\mathrm{t}$} & \multirow[b]{2}{*}{$\mathrm{p}$} \\
\hline & $\bar{x} \pm 6$ & & $\bar{x} \pm \sigma$ & & & \\
\hline $40-44$ & $0.55 \pm 1.17$ & - & $0.3 \pm 0.06$ & -21.4 & 0.65 & 0.52 \\
\hline $45-49$ & $1.42 \pm 2.04$ & - & $1.18 \pm 0.17$ & -11.5 & 0.35 & 0.73 \\
\hline $50-54$ & $8.9 \pm 6.08$ & 618.9 & $4.72 \pm 0.29$ & 13.4 & 2.06 & 0.06 \\
\hline $55-59$ & $18.24 \pm 7.78$ & -8.1 & $14.99 \pm 0.79$ & -6.0 & 1.24 & 0.23 \\
\hline $60-64$ & $51.69 \pm 14.08$ & 42.8 & $38.61 \pm 1.28$ & 2.1 & 2.77 & $0.01^{*}$ \\
\hline $65-69$ & $90.32 \pm 27.8$ & 96.4 & $75.81 \pm 2.67$ & 11.2 & 1.55 & 0.14 \\
\hline $70-74$ & $166.63 \pm 85.69$ & 209.3 & $130.19 \pm 7.22$ & 14.7 & 1.27 & 0.22 \\
\hline $75-79$ & $197.48 \pm 76.71$ & 113.7 & $188.79 \pm 11.15$ & 20.6 & 0.34 & 0.74 \\
\hline 80 and older & $142.38 \pm 51.98$ & 26.5 & $243.05 \pm 14.98$ & 18.6 & 5.59 & 0.00003 \\
\hline
\end{tabular}

*note: $\overline{\mathrm{x}}$ is average value, $\sigma$ is standard deviation; $\mathrm{t}$ is Student's test, $\mathrm{p}$ is significance level.

40-44 was the youngest age at which mortality caused by PC was detected in Kursk region ( 0.55 per 100 thousand men); it reached its peak among men aged 75-79 (197.48 per 100 thousand men) and then went down among those aged 80 and older. Authentically high discrepancies between mortality caused by $\mathrm{PC}$ in Kursk region against data collected in the RF were detected among men aged 60-64 (51.69 per 100 thousand men against 38.61 per 100 thousand men in the $\mathrm{RF}, \mathrm{t}=2.77, \mathrm{p}=0.01$ ). Mortality caused by PC among men aged 80 and older was 2 times higher in the country on average ( 243.05 per 100 thousand men) then in Kursk region (142.38 per 100 thousand men), $\mathrm{t}=5.59, \mathrm{p}=0.00003$.

Mortality caused by PC grew in 2016 against 2007 practically in all age groups of men in Kursk region; the highest growth was among those aged $50-54$, by $618.9 \%, 70-74$, by $209.3 \%$, and $75-79$, by $113.7 \%$ (Table 4 ); growth rates were not so high in all the age groups as regards the country in general.
Conclusion. So, incidence with prostate cancer in Kursk region, just as in most regions in the CFD grows due to an increase among men aged 60-64 and 80 and older. In Kursk region, risk for men younger than 60 to die from prostate cancer amounts to $1.45^{*} 10^{-4}$, and it is almost 3 times higher than the same parameter in the RF in general $\left(5.3 * 10^{-5}\right)$.

As per experts' forecasts, unless prevention activities are implemented, Kursk region can soon become one of those regions in the country where incidence with prostate cancer and mortality caused by it are the highest, an increase in mortality among men aged $50-65$ being a reason for it as well.

All the data obtained in the research are being applied to plan and develop «Oncology» regional program in Kursk region.

Funding. The research was not granted any sponsor support.

Conflict of interest. The authors state there is no any conflict of interests.

\section{References}

1. Center M.M., Jemal A., Lortet-Tieulent J., Ward E., Ferlay J., Brawley O. [et al.]. International variation in prostate cancer incidence and mortality rates. Eur. Urol., 2012, vol. 61, pp. 1079-1092.

2. Bashir M.N. Epidemiology of prostate cancer. Asian Pac. J. Cancer Prev., 2015, vol. 16, pp. 5137-5141. 
3. Pakzad R., Rafiemanesh H., Ghoncheh M., Sarmad A., Salehiniya H., Hosseini S. [et al.]. Prostate cancer in Iran: trends in incidence and morphological and epidemiological characteristics. Asian Pac. J. Cancer Prev., 2016, vol. 17, pp. 839-843.

4. Cook M.B., Rosenberg P.S., Mc Carty F.A., Wu M., King J., Eheman C. [et al.]. Racial disparities in prostate cancer incidence rates by census division in the United States, 1999-2008. Prostate, 2015, vol. 75, pp. 758-763.

5. Somdyala N.I., Parkin D.M., Sithole N., Bradshaw D. Trends in cancer incidence in rural Eastern Cape Province; South Africa, 1998-2012. Int. J. Cancer, 2015, vol. 136, pp. 470-474.

6. De Souza J.A., Hunt B., Asirwa F.C., Adebamowo C., Lopes G. Global health equity: cancer care outcome disparities in high-, middle-, and low-income countries. J. Clin. Oncol., 2016, vol. 34, pp. 6-13.

7. Ferlay J., Soerjomataram I., Dikshit R., Eser S., Mathers C., Rebelo M. [et al.]. Cancer incidence and mortality worldwide: Sources, Methods and Major Patterns in GLOBOCAN-2012. International Journal of Cancer, 2015, vol. 136, pp. E359-E386. DOI: 10.1002/ijc.29210

8. Wong M.C.S., Goggins W.B., Wang H.X., Fung F.D.H., Leung C., Wong S.Y.S., Fai $\mathrm{Ng}$ Ch., Joseph J.Y. Sung Global Incidence and Mortality for Prostate Cancer: Analysis of Temporal Patterns and Trends in 36 Countries. European Urology, 2016, vol. 70, pp. 862-874. DOI: 10.1016/j.eururo.2016.05.043

9. Lee D.J., Mallin K., Graves A.J., Chang S.S., Penson D.F., Resnick M.J., Barocas D.A. Recent Changes in Prostate Cancer Screening Practices and Epidemiology. The Journal of Urology, 2017, vol. 198, pp. 1230-1240. DOI: 10.1016/j.juro.2017.05.074

10. Kovshik V.S., Savrova O.B. Prostate cancer risk factor comparative analysis. Zdorov'e $i$ obrazovanie v XXI veke: Materialy XIX mezhdunarodnogo kongressa (Spetsial'nyi vypusk). Moscow, 2017, pp. 135-137. Available at: https: //cyberleninka.ru/article/n/sravnitelnyy-analiz-faktorovriska-razvitiya-raka-predstatelnoy-zhelezy (23.10.2018) (in Russian). DOI: 10.26787/nydha-22267417-2017-19-12

11. Kostin A.A., Asratov A.T., Kul'chenko N.G., Tolkachev A.O. Prediction of prostate cancer by the general discriminant analysis models. Vestnik RUDN. Seriya Meditsina, 2015, no. 3, pp. 67-74 (in Russian).

12. Kim S.P., Karnes R.J., Gross C.P., Meropol N.J., Van Houten H., Abouassaly R., Shah N.D. Contemporary National Trends of Prostate Cancer Screening Among Privately Insured Men in the United States. Urology, 2016, vol. 97, pp. 111-117. Available at: https: //www.ncbi.nlm.nih.gov/ pubmed/27527411 (22.10.2018).

13. Misra-Hebert A.D., Hu B., Kleyn E.A., Stephenson A., Taksler G.B., Kattan M.W., Rothberg M.B. Prostate cancer screening practices in a large, integrated health system: 2007-2014. BJU Int, 2017, vol. 120, no. 2, pp. 257-264. Available at: https: //www.ncbi.nlm.nih.gov/pubmed/28139034 (22.10.2018).

14. Falchook A.D., Chen R.C. Adjuvant vs. salvage radiotherapy for patients at high risk for recurrence after radical prostatectomy. Urol. Oncol., 2015, vol. 33, no. 11, pp. 451-455. Available at: https: //www.ncbi.nlm.nih.gov/pubmed/26814331 (22.10.2018).

15. Zlokachestvennye novoobrazovaniya v Rossii v 2017 godu (zabolevaemost' i smertnost') [Malignant neoplasms in Russia in 2017 (morbidity and mortality)]. In: A.D. Kaprina, V.V. Starinskii, G.V. Petrova eds. Moscow, MNIOI im. P.A. Gertsena filial FGBU «NMITs radiologii» Minzdrava Rossii Publ., 2018, 250 p. (in Russian).

16. Petrova N.G., Krotov K.Yu. Dynamics and forecast of morbidity and mortality from prostate cancer in St. Petersburg. Vestnik SPbGU. Meditsina, 2016, vol. 11, no. 1, pp. 127-133 (in Russian).

17. Petrova N.G., Krotov K.Yu., Balokhina S.A. Rak predstatel'noi zhelezy kak aktual'naya mediko-sotsial'naya problema [Prostate cancer as a pressing medical and social issue]. Vrach aspirant, 2014, vol. 62, no. 1, pp. 83-89 (in Russian).

18. Petrova G.V., Starinskii V.V., Gretsova O.P. Assessment of the quality of accounting of deaths of patients with malignant neoplasms in Russia. Issledovaniya i praktika v meditsine, 2016, vol. 3, no. 4, pp. 70-74 (in Russian). DOI: 10.17709/2409-2231-2016-3-4-8 
19. Kuchuk S.A., Maksimov A.V. The problem of forming accurate statistical reporting of causes of death. Sudebnaya meditsina, 2016, vol. 2, no. 3, pp. 17-19 (in Russian). DOI: 10.19048/2411-8729-2016-2-3-17-19

20. Organizatsiya onkologicheskoi sluzhby v Rossii (metodicheskie rekomendatsii, posobiya dlya vrachei) [Organization of oncologic service in Russia (methodical guidelines and manuals for physicians)]. Part 2. In: V.I. Chissov, V.V. Starinskii, B.N. Kovalev eds. Moscow, 2007, 663 p. (in Russian).

21 Dubrovskaya L.I. Prognozirovanie vremennykh ryadov v pakete Statistica: metodicheskie ukazaniya [Time series prediction in Statistica: methodical guidelines].Tomsk: Tomskii gosudarstvennyi universitet Publ., 2012, 36 p. (in Russian).

Kiselev I.L., Pol'shin A.A. Epidemiology of prostate cancer in Kursk region. Health Risk Analysis, 2019, no. 2, pp. 115-122. DOI: 10.21668/health.risk/2019.2.13.eng

Received: 31.10 .2018

Accepted: 13.06 .2019

Published: 30.06.2019 